\title{
REVITALISASI NILAI-NILAI KEARIFAN LOKAL MASYARAKAT HUKUM ADAT BATAK TOBA DALAM MELINDUNGI EKSISTENSI DANAU TOBA DI MATA DUNIA (KAJIAN HUKUM PROGRESIF)
}

\author{
Oleh: \\ Muhammad Ansori Lubis \\ Universitas Darma Agung, Medan \\ muhammadansorilubis3@gmail.com
}

\begin{abstract}
ABSTRAK
Adat adalah sebuah sistem yang mengatur kehidupan manusia. Masalah dalam penelitian ini dibagi kedalam tiga bagian, yaitu 1. Bagaimana Hubungan NilaiNilai kearifan Lokal masyarakat Hukum Adat 2. Batak Toba dalam melindungi kawasan Danau Toba? 3. Mengapa diperlukan revitalisasi nilai-nilai kearifan lokal kedalam Pembentukan Peraturan Hukum terkait perlindungan kawasan Danau Toba? Penelitian ini memberikan hasil bahwa hukum yang resposif diperlukan, aturan yang tidak tumpang tindih, koheren, dan konsistensi menjadi salah satu cara untuk memperbaiki kawasan Danau Toba dari jalur regulasinya. Pembentukan hukum yang memasukan nilai-nilai kearifan masyarakat merupakan perwujudan dari hukum yang responsive dan progresif untuk membentuk aturan yang memiliki nilai kepastian hukum, keadilan dan kemanfaatan. Penegakan hukum juga diperlukan bagi setiap tindakan masyarakat atau oknum tertentu yang melakukan pencemaran lingkungan agar menjadi contoh bagi masyarakat lain untuk tidak melakukan tindakan pencemaran.
\end{abstract}

Kata kunci: Danau Toba, Revitalisasi, Adat Batak Toba

\section{A. Pendahuluan}

Kawasan Danau Toba adalah kekayaan alam yang diberikan Tuhan yang Maha Kuasa kepada umat manusia khususnya Indonesia. Pelestarian kawasan Danau Toba sudah dilakukan sejak lama, bahkan menjadi perhatian dunia internasional dengan menjadikan Danau Toba termasuk dalam warisan dunia.

Danau Toba adalah danau kaldera terbesar di dunia yang terletak di Provinsi Sumatera Utara, berjarak $176 \mathrm{~km}$ ke arah Barat Kota Medan sebagai ibu kota provinsi. Danau Toba $(2,88$ o N - 98,5o 2E dan 2,35o $\mathrm{N}-99,1$ o E) adalah danau terluas di Indonesia $(90 \times 30 \mathrm{~km} 2)$ dan juga merupakan sebuah kaldera volkano-tektonik (kawah gunung api raksasa) Kuarter terbesar di dunia. Sebagai danau volcano tektonik terbesar di dunia, Danau Toba mempunyai ukuran panjang $87 \mathrm{~km}$ berarah Baratlaut-Tenggara dengan lebar $27 \mathrm{~km}$ dengan ketinggian 904 meter dpl dan kedalaman danau yang terdalam 505 meter.

Jumlah penduduk di kawasan Danau Toba Tahun 2013 lebih kurang 951.711 Jiwa yang tersebar di 8 Kabupaten dan 61 Kecamatan. Jumlah penduduk tertinggi berada di Kecamatan Sidikalang, Kabupaten Dairi dengan jumlah 47.272 jiwa dan 
terendah berada di Kecamatan Muara, KabupatenTapanuli Utara dengan jumlah 1.355 jiwa.Kepadatan rata-rata penduduk di kawasan Danau Toba Tahun 2013 adalah 110 jiwa/km2. Kepadatan tertinggi berada di Kecamatan Sidikalang, Kabupaten Dairi yaitu 669 jiwa/km2, sedangkan kepadatan penduduk terendah berada di Kecamatan Muara, Kabupaten Tapanuli Utara yaitu 17 jiwa/km2.

Keindahan Danau Toba serta kelimpahan sumberdaya alamnya menjadi daya tarik bagi masyarakat. Seiring dengan perjalanan waktu, jumlah penduduk yang berdomisili semakin meningkat dengan demikian juga pemanfaatan dan jenis pemanfaatan sumberdaya alam semakin meningkat dan bervariasi. Beberapa pemanfaatan Danau Toba untuk keperluan masyarakat antara lain sebagai sumber air minum, pembangkit listrik dan budi daya ikan.

Akibat dari aktivitas masyarakat sekitar Danau Toba, saat ini kawasan Danau Toba telah mengalami pencemaran, terlebih karena kegiatan pembudidayaan ikan yang tepat berada dikawasan Danau Toba.

Salah satu penyebab lain kerusakan Daerah Tangkan Air adalah penambangan bahan galian golongan $\mathrm{C}$ dari badan air, pinggiran pantai dan tebing Danau Toba. Penambangan ini memang memberi manfaat ekonomi, namum pada saat yang sama juga menimbulkan kerusakan lingkungan yang massif. Tebing danau yang berupa bebatuan digali bahkan sampai mencapai puncak tebing. Penambangan ini sangat merusak ekosistem, menimbulkan erosi, sedimentasi, kekeruhan, menambah lahan kritis dan berpeluang untuk melongsorkan/meruntuhkan dinding Danau Toba.

Selain kerusakan lingkungan seputar Danau Toba, terjadi juga pada keanekaragaman hayati pada kawasan Danau Toba telah mengalami ancaman, baik habitat daratan maupun habitat perairan. Terdapat berbagai faktor penyebab terancamnya keanekaragaman hayati pada kawasan ini diantaranya; perusakan habitat karena kebakaran, konversi lahan, aplikasi pestisida, pembuangan limbah, penyempitan luasan habitat, introduksi spesies asing, maupun serangan hama dan penyakit serta bencana alam banjir, longsor atau gempa. Pada saat ini terjadi blooming ikan Pora-pora (Puntius binotatus) di Danau Toba dan pada saat yang sama nelayan kesulitan menangkap ikan mujair (Tilapia mossambica), salah satu spesies asli danau ini yang sudah mulai sulit ditemukan di perairan Danau Toba.

Pemerintah

Republik Indonesia dan Pemerintah Daerah Provinsi Sumatera Utara, Kabupaten Samosir, Kabupaten Toba Samosir, Kabupaten Dairi, Kabupaten Karo, Kabupaten Humbang Hasundutan, Kabupaten Tapanuli Utara, Kabupaten Simalungun Kabupaten Pakpak Barat ikut memiliki tanggung jawab hukum dan moral atas kerusakan kawasan Danau Toba.

Regulasi nasional dan daerah yang terkait dengan kawasan Danau Toba hingga detik ini belum pernah dilakukan pengkajian sinkronisasi, koherensi dan akuntabilitas dan liability (tanggungjawab) terhadap semua aturan yang mengatur hal-hal terkait dikawasan Danau Toba. Misalnya Undang-Undang Nomor 32 tahun 2009 Tentang Perlindungan 
dan Pengelolaan Lingkungan Hidup, Undang-Undang Nomor 10 Tahun 2009 tentang Kepariwisataan, Peraturan Presiden Nomor 81 Tahun 2014 tentang Rencana Tata Ruang Kawasan Danau Toba dan Sekitarnya, dan Peraturan Presiden Nomor 49 tahun 2016 tentang Badan Otorita Pengelola Kawasan Pariwisata Danau Toba. Beberapa aturan tersebut merupakan regulasiregulasi tingkat nasional yang secara langsung memberikan perlindungan bagi kawasan Danau Toba. Hanya saja jika melihat pratiknya, ternyata regulasi tersebut belum secara keseluruhan menjadi rule/model bagi pemerintah daerah untuk membentuk aturan yang signifikan yang memberikan perlindungan kepada kawasan Danau Toba dan juga aturan/regulasi tersebut belum secara keseluruhan memberikan jaminan bahwa tidak terjadi perusakan dan pencemaran dikawasan Danau Toba sampai saat ini.

Sebenarnya jika melihat keadaan masyarakat sekitar Danau Toba, yang mayoritas adalah suku Batak dimana suku Batak adalah suku yang sampai saat ini masih mempertahankan nilai-nilai kearifan lokal. Untuk itu, kerusakan dan pencemaran yang terjadi saat ini dikawasan Danau Toba menjadi sebuah tanda tanya besar, mengapa hal tersebut bisa terjadi ? Hingga dunia internasional menaruh perhatian lebih pada kawasan Danau Toba, sedangkan masyarakat disekitar Danau Toba yang notabene nya adalah masyarakat hukum adat yang masih eksis keberadaannya. Oleh karena itu, penulis tertarik untuk melakukan kajian singkat terhadap perlindungan kawasan Danau Toba dengan judul, Revitalisasi Nilai-nilai Kearifan
Lokal Masyarakat Hukum Adat Batak Toba dalam Melindungi Eksistensi Danau Toba di Mata Dunia (Kajian Hukum progresif).

\section{B. Rumusan Masalah}

Dalam kajian ini, yang menjadi batasan permasalahan yang kemudian dijadikan sebagai rumusan masalah adalah sebagai berikut:

1. Bagaimana Hubungan NilaiNilai kearifan Lokal masyarakat Hukum Adat Batak Toba dalam melindungi kawasan Danau Toba?

2. Mengapa diperlukan revitalisasi nilai-nilai kearifan lokal kedalam Pembentukan Peraturan Hukum terkait perlindungan kawasan Danau Toba?

\section{Kajian Teori}

1. Teori Hukum Progresif Satjipto Rahardjo

Perspektif Teori hukum progresif yang dipelopori oleh Satjipto Rahardjo, sebuah padanan hukum tidak hanya terletak hanya pada aturan teknis semata pembentukan aturan tersebut tetapi juga dalam pembentukan hukum harus memperhatikan dan mengkokohkan asas hukumnya agar memiliki pondasi yang kuat.

Menurut Satjipto Rahardjo, pembahasan mengenai asas hukum adalah membicarakan unsur yang penting dan pokok dari peraturan hukum dan tidak berlebihan pula jika dikatakan bahwa asas hukum merupakan jantung dari peraturan hukum. Hal ini dikarenakan asas hukum adalah landasan yang paling luas bagi lahirnya suatu peraturan hukum. Ini berarti bahwa setiap peraturan hukum selalu bisa dikembalikan kepada asas-asas tersebut. 
Menurut Paton sebagaimana dikutip oleh Satjipto Rahardjo menyatakan bahwa asas hukum adalah sarana yang membuat hukum itu hidup, tumbuh dan berkembang dan ia juga menunjukkan bahwa hukum itu bukan sekedar kumpulan dari peraturan-peraturan belaka. Hukum memiliki titik pandang dan akan bertolak dari situ pula. Dalam hukum titik pandang itu terdapat pada asas hukum. Asas hukum bukanlah peraturan seperti pasalpasal undang-undang, namun sebagaimana dikatakan Scholten, hukum tidak dapat dipahami dengan baik tanpa asas- asas.

Asas hukum menjadikan hukum lebih dari sekedar peraturan yang dibuat dengan sengaja dan rasional, tetapi juga suatu dokumen moral-etis. Asas hukum memang tidak tampil sebagai aturan (rule) yang konkrit, tetapi lebih sebagai kaidah (norm) di belakang peraturan. Aturan itu rasional, sedangkan kaidah memiliki kandungan moral dan bersifat etis. Asas hukum menjelaskan dan memberi ratio legis mengapa harus ada aturan. Ia menjadi penghubung antara peraturan hukum dan cita-cita sosial serta pandangan etis masyarakatnya.

Hukum progresif melihat dunia dan hukum dengan pandangan yang mengalir saja, seperti "panta rei" (semua mengalir) dari filsuf Heraklitos. Apabila orang berkeyakinan dan bersikap seperti itu, maka ia akan membangun suatu cara berhukum yang memiliki karakteristiknya sendiri, sebagaimana akan diuraikan di bawah ini.

Pertama, paradigma dalam hukum progresif adalah bahwa "hukum adalah untuk manusia". Pegangan, optik, atau keyakinan dasar ini tidak melihat hukum sebagai sesuatu yang sentral dalam berhukum, melainkan manusialah yang berada dititik pusat peraturan hukum. Hukum itu berputar di sekitar manusia sebagai pusatnya. Hukum ada untuk manusia, bukan manusia untuk hukum. Apabila kita berpegangan pada keyakinan, bahwa manusia itu adalah untuk hukum, maka manusia itu akan selalu diusahakan, mungkin juga dipaksakan, untuk bisa masuk ke dalam skema-skema yang telah dibuat oleh hukum.

Kedua, hukum progresif menolak untuk mempertahankan keadaan status quo dalam berhukum. Mempertahankan status quo memberi efek yang sama, seperti pada waktu orang berpendapat, bahwa hukum adalah tolok ukur untuk semuanya, dan manusia adalah untuk hukum. Cara berhukum yang demikian itu sejalan dengan cara positivistik, normatif dan legalistik. Sekali undang-undang mengatakan atau merumuskan seperti itu, kita tidak bisa berbuat banyak, kecuali hukumnya dirubah lebih dulu.

Namun, menurut Satjipto Rahardjo, pengalaman di lapangan menunjukkan betapa kompleksnya masalah dan bekerjanya hukum. Hukum tidak selalu sejelas, segampang, dan sesederhana seperti dibayangkan orang, kendati dikatakan, hukumnya sudah jelas. Hukum adalah dokumen yang terbuka untuk atau mengundang penafsiran. Undang-undang yang dirasakan tidak adil oleh masyarakat mungkin akan ditidurkan (statutory dormancy) atau dikesampingkan (desuetudo).

Menurut Satjipto Rahardjo, dalam nada yang mungkin agak ekstrim dapat dikatakan bahwa 
keberhasilan atau kegagalan para penegak hukum dalam melaksanakan tugasnya sebetulnya sudah dimulai sejak peraturan hukum yang harus dijalankan itu dibuat.

\section{Pembahasan}

\section{Hubungan Nilai-Nilai Kearifan} Lokal Masyarakat Hukum Adat Batak Toba Dalam Melindungi Kawasan Danau Toba

Masyarakat yang berbudaya hidup dari berbagai faktor yang menentukan cara kehidupan masyarakat. Disamping lingkungan dan teknologi, faktor lain adalah organisasi sosial dan politik berpengaruh dalam memenuhi kebutuhan sehari-hari. Unsur-unsur itu disebut dengan inti kebudayaan, meliputi kemampuan pengetahuan masyarakat terhadap sumber daya yang ada. Inti kebudayaan itu, menjelaskan lebih luas dalam mempengaruhi pola kehidupan dalam lingkungan lokal masyarakat Batak Toba. Para etnosains percaya bahwa ideologi sebuah masyarakat terhadap prinsip-prinsip itu biasanya untuk mempertahankan kelangsungan hidup komunitasnya.

Kebudayaan Batak Toba merupakan sebuah bentuk gagasan yang diwarisi masyarakat pemiliknya dengan membuat perilaku terhadap nilai-nilai budaya. Konsep masyarakat Batak Toba tentang kehidupan manusia, adalah bahwa kehidupannya selalu terkait dan diatur oleh nilai-nilai adat. Adat merupakan bagian dari kewajiban yang harus ditaati dan dijalankan.

Berdasarkan hasil kajian dari MA. Sianturi, menyebutkan bahwa dalam praktek pelaksanaan adat Batak Toba, realita di lapangan menunjukkan terdapat empat (4) katagorial adat yang telah dilakukan.
Pertama, komunitas masyarakat Batak Toba mempunyai sistem hubungan adat tersendiri. Menunjukkan, setiap komunitas mempunyai tipologi adat masingmasing. Perlakuan masyarakat pedesaan terhadap adat lebih intensif dan merekat, dengan masyarakat Batak yang tinggal di perkotaan relatif lebih individualistis menyikapi adat Batak. Perilaku ini muncul akibat pengaruh lingkungan yang membentuk pola pikir disamping unsur teknologi yang mempengaruhi.

Kedua, Adat yang diyakini sebagai norma yang mengatur hubungan antar manusia Batak Toba, dipengaruhi oleh aturan dan norma yang sudah berlaku dalam masyarakatnya. Peraturan perundang-undangan dan hukum agama yang banyak mengatur kehidupan normatif masyarakat secara rinci dan detail, memperkecil peranan adat dalam mengatur norma sosial dan kehidupan bermasyarakatnya. Seiring pula dengan aturan perundang-undangan dan hukum agama yang sudah membudaya, sering juga dipandang dan dianggap sebagai bagian dari adat istiadat Batak Toba sendiri.

Ketiga, Pola hubungan antar manusia dalam kelompok masyarakat Batak Toba berubah secara terus menerus, sehingga pelaksanaan adatnya juga mengalami perubahan sesuai kebutuhan tanpa melihat sisi ruang dan waktu.

Keempat, pandangan dan nilai yang diberikan terhadap adat itu juga mengalami perubahan, akibat dari pengaruh teknologi dalam penyebarluasan informasi. Hal itu tampak dalam praktek adat yang dilakukan oleh masyarakat pendukungnya. 
Adat adalah sebuah sistem yang mengatur kehidupan manusia. Sehingga, orang Batak yang bertindak dan bertingkah laku tidak sesuai dengan adat disebut dengan $n a$ so maradat (orang yang tidak memiliki adat) dan akan ada sanksi sosial terhadap orang-orang yang melanggar adat.

Dalam masyarakat hukum adat Batak Toba, dikenal beberapa nilainilai sakral dalam sistem adat diataranya:

\section{Kekerabatan}

Nilai kekerabatan masyarakat Batak utamanya terwujud dalam pelaksanaan adat Dalian $\mathrm{Na}$ Tolu, dimana seseorang harus mencari jodoh diluar kelompoknya, orangorang dalam satu kelompok saling menyebut Sabutuha (bersaudara), untuk kelompok yang menerima gadis untuk diperistri disebut Hulahula. Kelompok yang memberikan gadis disebut Boru.

2. Hagabeon

Nilai budaya yang bermakna harapan panjang umur, beranak, bercucu banyak, dan yang baik-baik.

\section{Hamoraon}

Nilai kehormatan suku Batak yang terletak pada keseimbangan aspek spiritual dan meterial.

4. Uhum dan ugari

Nilai uhum orang Batak tercermin pada kesungguhan dalam menegakkan keadilan sedangkan ugari terlihat dalam kesetiaan akan sebuah janji.

\section{Pengayoman}

Pengayoman wajib diberikan terhadap lingkungan masyarakat, tugas tersebut di emban oleh tiga unsur Dalihan Na Tolu.

6. Marsisarian

Suatu nilai yang berarti saling mengerti, menghargai, dan saling membantu.
Berdasarkan uraian singkat di atas, jika melihat kepada persoalan lingkungan (kawasan Danau Toba), penerapan nilai-nilai adat pada masyarakat Batak Toba menjadi sebuah aktivitas sehari-hari yang dilaksanakan setiap warga masyarakat yang bertempat tinggal di seputar kawasan Danau Toba. Nilai pengayoman dan Marsisarian yang merupakan repsentasi/perwujudan perilaku masyarakat adat batak toba untuk menjaga lingkungan, saling menghargai dan menghormati sesama masyarakat dan lingkungan.

Sejatinya, masyarakat hukum adat batak, secara konsep adat telah memiliki nilai-nilai kearifan lokal dalam wujud petuah-petuah adat yang secara keseluruhan masyarakat adat Batak wajib untuk mentaatinya. Hal tersebut menjadi norma bagi masyarakat adat yang wajib untuk dipatuhi dan dilaksanakan.

Selain itu, tatanan nilai-nilai sosial masyarakat hukum adat batak juga mengatur mengenai keberadaan kawasan hutan adat, dimana kawasan hutan yang terletak diseputar kawasan Danau Toba merupakan tempat untuk mencari kehidupan bagi masyarakat Batak. Tanah bagi masyarakat Batak merupakan sebuah tempat yang harus dilindungi dan dilestarikan keberadaannya guna kelangsungan hidup ke depan.

Dalam konsep masyarakat hukum adat Batak, seluruh kehidupan tertuju pada daya dan upaya untuk mencapai kepemilikan sahala. Sahala dalam filsafat masyarakat hukum adat Batak sangat besar pengaruhnya dalam segala gerak hidup orang Batak, dan semua orang Batak harus mempunyai sahala. Penafsiran sahala menurut Warneck adalah kewibawaan hidup, 
kekayaan akan harta benda dan keturunan, kemuliaan yang mencakup kebijaksanaan, kecerdikan, kecerdasan, kekuasaan, keluhuran budi pekerti. Hal ini terus dilakukan oleh orang Batak secara turun temurun. Implementasinya, nampak pada setiap pekerjaan adat dan hubungan kehidupan antara orang Batak. Sehingga sahala adalah wujud dari hagabeon, hamoraon dan hasangapon. Sahala adalah perwujudan roh (tondi) dalam kehidupan manusia di dunia. Dia merujuk pada sebuah kekuatan nyata yang menjadi milik orang-orang penting dan kuat. Tanda utama kepemilikan sahala yang besar adalah dimana seseorang memiliki keberhasilan duniawi. Sahala merupakan sebuah kualitas yang bisa diperoleh atau hilang. Masyarakat Batak Toba memberi tingkatan hidup pada nilai-nilai kebudayaan dalam tiga kata, yaitu harajaon (kuasa), hamoraon (kekayaan) dan hasangapon (kehormatan).

Terjadinya

pencemaran

kawasan Danau Toba oleh kegiatan manusia tidak terlepas dari faktor bahwa eksistensi nilai-nilai adat masyarakat adat Batak hanya dijadikan symbol belaka, tidak dilaksanakan dalam kehidupan sehari-hari, sementara pemerintah tidak memperhatikan bahwa begitu penting nilai-nilai kearifan lokal itu untuk mempertahankan kelestarian alam Danau Toba.

Pergeseran nilai dan perilaku hidup masyarakat Batak yang pada mulanya memanfaatkan Danau Toba menjadi sumber kehidupan saat ini telah jauh dari harapan, ketidakpedulian masyarakat dan generasi muda untuk menerapkan filosofi adat Batak dalam kesehariannya menjadikan sistem adat hanya tinggal sebatas konsepsi semata, tidak berlaku.

Saat ini, filosofi masyarakat hukum adat Batak harus terus dilestarikan dan diperkenalkan bagi setiap generasi penerus masyarakat suku adat Batak maupun diperkenalkan kepada masyarakat luar. Para tetua adat, tokoh masyarakat, pemerintah harus mengakui dan melindungi eksistensi/keberadaan nilai-nilai kearifan lokal masyarakat Batak dalam kesehariannya.

Terkait dengan perlindungan kawasan Danau Toba, apabila filosofi masyarakat adat Batak terus dilestarikan maka secara tidak langsung masyarakat hukum adat Batak akan dapat terus mempertahankan keberadaan kawasan Danau Toba yang sehat, bersih dan lestari, sehingga kawasan Danau Toba dapat terus memberikan penghidupan bagi sebagian besar masyarakat hukum adat yang tinggal dikawasan tersebut. Bagi masyarakat luar, pembelajaran nilai-nilai filosofi masyarakat adat Batak penting untuk diketahui untuk cerminan bahwa masyarakat Indonesia memiliki keanekaragaman adat istiadat yang banyak memiliki kandungan nilai dan etika moral yang baik untuk diterapkan dalam keseharian.

\section{Revitalisasi Nilai-Nilai Kearifan Lokal kedalam Pembentukan Peraturan Hukum terkait Perlindungan Kawasan Danau Toba}

Perlindungan kawasan Danau Toba merupakan tugas bersama baik itu dari pemerintah pusat maupun pemerintah daerah, serta masyarakat. Secara konsepsi hukum, bahwa perlindungan lingkungan hidup telah diatur dalam Undang-Undang Dasar 
dan peraturan pelaksana lainnya seperti Undang-Undang Nomor 32 Tahun 2009 tentang Perlindungan dan Pengelolaan Lingkungan Hidup (UUPLH). Selain tingkat nasional, regulasi daerah juga menjadi sebuah bentuk perlindungan hukum bagi lingkungan (kawasan Danau Toba).

Didalam pembentukan hukum, secara formal telah diatur dalam Undang-undang Nomor 12 Tahun 2011 tentang Pembentukan peraturan perundang-undangan. $\mathrm{Di}$ dalam undang-undang tersebut terdapat beberapa asas pembentukan aturan hukum yakni:

Pasal 5 menyebutkan bahwa : Dalam membentuk Peraturan Perundang-undangan harus dilakukan berdasarkan pada asas Pembentukan Peraturan Perundangundangan yang baik, yang meliputi:
a. kejelasan tujuan;
b. kelembagaan atau pejabat pembentuk yang tepat;
c. kesesuaian antara jenis, hierarki, dan materi muatan;
d. dapat dilaksanakan;
e. kedayagunaan dan kehasilgunaan;
f. kejelasan rumusan; dan
g. keterbukaan

Pasal 6 menyebutkan bahwa : (1) Materi muatan Peraturan Perundangundangan harus mencerminkan asas:
a. pengayoman;
b. kemanusiaan;
c. kebangsaan;
d. kekeluargaan;
e. kenusantaraan;
f. bhinneka tunggal ika;
g. keadilan;
h. kesamaan kedudukan dalam hukum dan pemerintahan;
i. ketertiban dan kepastian hukum; dan/atau
j. keseimbangan, keserasian, dan keselarasan.

Berlakunya asas hukum tersebut tidak hanya pada tingkat undang-undang semata, tetapi juga didalam regulasi daerah atau peraturan daerah. Pembentukan hukum/aturan yang baik adalah aturan yang telah memenuhi syarat formal dan material.

Terkait dengan perlindungan kawasan Danau Toba, pemerintah daerah yang berada dikawasan Danau Toba memiliki peran penting baik secara sendiri-sendiri maupun bersama-sama untuk bertanggung jawab atas kelestarian dari Danau Toba.

Pada tahun 2004 Pemerintah Daerah kabupaten Asahan, kabupaten Dairi, kabupaten Toba Samosir, kabupaten Humbang hasundutan, kabupaten Karo, kabupaten Simalungun, kota Tanjungbalai, kabupaten Tapanuli Utara, telah membentuk sebuah kesepakatan bersama untuk melindungi kawasan ekosistem Danau Toba yang dideklarasikan di Parapat.

Hal tersebut merupakan rangkaian tindakan secara bersamasama untuk melindungi kawasan Danau Toba dari kerusakan lingkungannya. Sudah hampir 13 tahun kesepakatan tersebut dibentuk, akan tetapi tidak menimbulkan implikasi yang berarti bagi kawasan Danau Toba. Bahkan sebaliknya, kawasan Danau Toba saat ini menjadi kawasan yang eksosistemnya terancam punah.

Perlindungan kawasan Danau Toba dari kerusakan telah dilakukan oleh pemerintah yang dimulai dengan inisiatif Geopark/Taman bumi Kaldera Toba (GKT) dimulai sejak awal tahun 2011 oleh Kementerian Pariwisata dan Kebudayaan karena memiliki kaitan 
erat dengan sejarah pembentukan bumi ini. Ekspedisi Cincin Api Kompas September 2011, semakin mengungkap bahwa Gunung Toba yang memunculkan Kaldera Danau Toba pernah mengubah dunia.

Disambut oleh Pemerintah lokal dan provinsi serta sekelompok masyarakat sipil, inisiatif GKT pun dikukuhkan Presiden Susilo Bambang Yudhoyono sebagai Geopark Nasional, Lalu, di daftarkan kepada Badan Pendidikan, Ilmu Pengetahuan, dan Kebudayaan (UNESCO) PBB, akhir Oktober 2014.

Asesor dari UNESCO telah melakukan penilaian lapangan terhadap dokumen usulan (dossier) GKT tersebut, dibalik kerusakan ekologi Danau Toba tersimpan potensi menakjubkan. Air tawar menyerupai lautan dihiasi dindingdinding kaldera ciptaan alam 74.000 tahun lampau. Batu-batu Toba yang menempel di setiap sudut kecantikannya siap diajak bercerita.

Kuatir, sebab luar-dalam fisik Danau Toba selama ini cenderung terabaikan. Meski berkali-kali diulas berbagai media dan para pencinta Danau Toba atas kerusakan dan minimnya infrastruktur kawasan ini, pemerintah belum mengambil kebijakan tegas. Dengan kata lain, pemerintah bersikap setengah hati. Padahal Danau Toba telah ditetapkan Kawasan Strategis Nasional, artinya objek vital Negara ini harus mendapat perhatian prioritas.

Warga lokal pun hanya menjadi pelengkap penderita atas investasi multinasional selama ini, jelas tidak menguntungkan Negara dalam jangka panjang. Salah satu poin, mudah menilai, kerusakan ekologi suatu kawasan di seluruh tanah air termasuk Danau Toba sekitarnya adalah konsekuensi kebijakan pemerintah bersifat eksploitatif, minus perlindungan. Alhasil, hari-hari berlalu dipastikan menuai kekecewaan, berikut ancaman bencana. Sejarah Danau Toba sebagai satu-satunya supervolcano dunia, mengubah iklim global, menyimpan misteri masa dulu hingga kini, danau volcano terbesar dunia dan penyimpan cadangan air tawar terbesar dunia, eksistensi sosiokultural dan aneka flora-fauna di dalamnya, itulah alasan Danau Toba dipromosikan pemerintah sebagai Geopark Nasional dan didaftarkan ke Jaringan Geopark Global, UNESCO.

Berbagai tindakan telah dilakukan oleh pemerintah pusat untuk menjaga kelestarian kawasan Danau Toba dari pencemaran dan kerusakan, hanya saja tindakantindakan yang dilakukan pemerintah tersebut sebenarnya hanya membawa perubahan diatas kertas dan hingga saat ini belum mampu untuk membalikkan keadaaan alam Danau Toba itu menjadi kawasan yang asri.

Danau toba sebagai kawasan wisata yang sangat terkenal di Indonesia maupun mancanegara. Yanti D (2019).

Prioritas perlindungan kawasan Danau Toba yang telah banyak tertuang dalam himpunan peraturan, harus memerlukan kajian yang komprensif dan berkelanjutan. Terbentuknya aturan formal seperti Peraturan Presiden Nomor 49 Tahun 2016 Tentang Badan Otorita Pengelola Kawasan Pariwisata Danau Toba yang notabenenya memberikan perubahan tetapi hanya tinggal aturan tekstual semata, didalam pelaksanannya masih jauh dari harapan. 
Merujuk pada teori hukum progresif Satjipto Rahadrjo, bahwa hukum yang baik itu bukanlah hanya aturan diatas kertas/tekstual semata, tetapi lebih kepada bagaimana perilaku penguasa dan aparat serta masyarakat dalam melaksanakan hukum. Untuk itu, pembentukan hukum yang baik harus mengkomodir aspirasi masyarakat dari bawah ke atas (down top) bukan sebaliknya dari atas turun ke bawah (top down).

Keterlibatan masyarakat dalam pembentukan aturan menjadi sebuah kunci untuk peraturan itu dapat ditaati masyarakat secara sukarela tanpa dipaksakan. Terkait dengan perlindungan kawasan Danau Toba, masyarakat hukum adat Batak memiliki peran penting dan signifikan dalam melestarikan kawasan Danau Toba tersebut, bukan kepentingan negara lain yang dapat membawa perubahan. Untuk itu, diperlukan revitalisasi nilai-nilai kearifan lokal kedalam setiap pembentukan aturan yang terkait dengan keberadaan kawasan Danau Toba baik dalam bentuk undangundang maupun peraturan daerah. Hal tersebut bertujuan agar masyarakat hukum adat batak yang secara langsung berhadapan dengan keadaan Danau Toba dapat tersadarkan dan secara sukarela ikut serta terus mempertahankan lingkungan Danau Toba.

Menggali kembali filosofi masyarakat Batak dan menempatkan nya kedalam aturan dikawasan Danau Toba menjadi salah satu jalan keluar untuk memperbaiki kawasan Danau Toba dari kerusakan.

Pemerintah daerah juga memiliki peran penting, persoalan tercemarnya kawasan Danau Toba tidak lepas dari persoalan perijinan yang dikeluarkan oleh Pemerintah Provinsi Sumatera Utara maupun pemerintah lokal daerah, dalam rangka memberikan ijin usaha kepada investor untuk melakukan kegiatan usaha di kawasan Danau Toba.

Peternakan ikan misalnya, yang dari beberapa penelitian menyebutkan bahwa adanya keramba/ternak ikan dikawasan Danau Toba lah yang menjadi faktor utama penyebab rusaknya ekosistem di Danau Toba. Hal tersebut terjadi karena, ijin yang diberikan oleh pemerintah setempat tidak dilakukan pengawasan. Setelah pengusahan mendapatkan ijin usaha, pemerintah daerah tidak melakukan koordinasi dan pemantauan terhadap usahanya. Setelah adanya kerusakan barulah kemudian pemerintah daerah melakukan tindakan. Hal tersebut tidak mencerminkan prinsip pelaksanaan good corporate governance, maka untuk itu, pemerintah daerah setempat mulai saat ini harus lebih intens memperhatikan persoalan ijin terkait dengan usaha yang berada di kawasan Danau Toba.

\section{E. Penutup}

Kompleksitas permasalahan di kawasan Danau Toba menjadi sebuah tantangan yang harus dihadapi oleh pemerintah pusat dan daerah serta masyarakat untuk segera diselesaikan. Pembentukan regulasi, kebijakan dan upaya internasional yang dilakukan pemerintah pusat dan daerah layak diberikan apresiasi karena bertujuan untuk mempertahankan kawasan Danau Toba dari kerusakan dan pencemaran.

Pembentukan hukum yang resposif diperlukan, aturan yang 
tidak tumpang tindih, koheren, dan konsistensi menjadi salah satu cara untuk memperbaiki kawasan Danau Toba dari jalur regulasinya. Pembentukan hukum yang memasukan nilai-nilai kearifan masyarakat merupakan perwujudan dari hukum yang responsive dan progresif untuk membentuk aturan yang memiliki nilai kepastian hukum, keadilan dan kemanfaatan. Penegakan hukum juga diperlukan bagi setiap tindakan masyarakat atau oknum tertentu yang melakukan pencemaran lingkungan agar menjadi contoh bagi masyarakat lain untuk tidak melakukan tindakan pencemaran.

\section{DAFTAR PUSTAKA}

Satjipto Rahardjo, 2006, Ilmu Hukum, PT Citra Aditya Bakti, Bandung.

dalam Jagat Ketertiban
Jakarta: UKI Press.
Hukum Mengalir, Jakarta:
Penertbit Buku Kompas.
http://repository.usu.ac.id/bitstream/1
23456789/32732/4/Chapter
II.pdf
http://dominique122.blogspot.co.id/2
015/04/masyarakat-batak-toba-
di-bona.html
http://spiritriau.com/view/Opini/5245
6/Menimbang-Inisiatif-
Geopark-Kaldera
Toba.html\#.V7U2FaKuhX0
www.pu.go.id/../infopublik2016033
0174236.pdf
Undang-Undang Dasar Negara
Republik Indonesia tahun 1945

Undang-Undang Nomor 32 tahun 2009 tentang Perlindungan dan Pengelolaan Lingkungan Hidup

Undang-Undang Nomor 24 tahun 2014 tentang Pemerintah Daerah

Undang-Undang Nomor 12 tahun 2011 tentang Pembentukan Peraturan Perundang-undangan Peraturan Presiden Nomor 49 tahun 2016 tentang Badan Otoritas Pengelolaan Kawasan Pariwisata Danau Toba

Yanti, D. (2019). ANALISIS STRATEGI PENGEMBANGAN

DIGITAL TOURISM SEBAGAI PROMOSI PARIWISATA DI TOBA SAMOSIR. Jurnal Darma Agung, 27(1), 814 - 821. Retrieved from https://jurnal.darmaagung.ac.id /index.php/jurnaluda/article/vie $\underline{\mathrm{w} / 137}$ 